\title{
Status Keberlanjutan Pengelolaan Sampah Terpadu di TPST- Bantargebang Bekasi: Menggunakan Rapfish dengan R Statistik
}

\author{
Tatan Sukwika ${ }^{1}$ dan Linda Noviana ${ }^{1}$
}

1Program Studi Teknik Lingkungan, Fakultas Teknik, Universitas Sahid; e-mail: tatan.swk@gmail.com

\begin{abstract}
ABSTRAK
Studi mengenai status keberlanjutan dari pengelolaan sampah dari DKI Jakarta secara terpadu di TPST (Pengelolaan Tempat Pengolahan Sampah Terpadu) Bantargebang Bekasi masih cukup terbatas, dan umumnya hanya membatasi pada lingkup pencemaran, masalah sosial, dan isu perluasan kawasan TPA. Salah satu konsep pembangunan TPST tersebut adalah pengelolaan sampah yang lebih ramah lingkungan, berteknologi, dan terkoordinasi. Studi ini berfokus pada evaluasi pengelolaan sampah terpadu di TPST Bantargebang saat ini. Data yang dikumpulkan dalam penelitian ini, meliputi data primer dan sekunder. Data primer dihimpun dari wawancara pakar, sedangkan data sekunder dari laporan, jurnal dan hasil-hasil kajian berbagai instansi terkait. Teknik analisis menggunakan multi-dimensional scalling Rapfish yang diintegrasikan ke dalam perangkat lunak R statistik. Hasil studi menunjukkan status keberlanjutan pengelolaan sampah terpadu di TPST-Bantargebang antar stakeholder sangat beragam, secara rataan nilai indeks multidimensional berkisar di 51,71 pada tingkat determinasi 97 persen dan menghasilkan 15 atribut sensitif yang berpengaruh terhadap pengelolaan sampah terpadu di TPST-Bantargebang. Simpulannya, secara keseluruhan status keberlanjutan pengelolaan sampah terpadu di TPST-Bantargebang termasuk dalam kategori berkelanjutan (lulus).
\end{abstract}

Kata kunci: Multi-dimensional scalling, Pengolahan sampah terpadu, R statistik, TPST Bantargebang

\begin{abstract}
The study of the sustainability status of solid waste management from DKI Jakarta in TPST (Integrated Waste Management) Bantargebang Bekasi is quite limited, and generally only limits the scope of pollution, social problems, and the issue of landfill expansion. One of the TPST development concepts is waste management that is more environmentally friendly, technologically, and coordinated. This study focuses on evaluating of integrated waste management in the Bantargebang TPST. Data collected in this study include primary and secondary data. Primary data was collected from expert interviews, while secondary data from reports, journals and the results of studies of various related agencies. The analysis technique uses multi-dimensional scaling of Rapfish which is integrated into the R statistics software. The results of the study show the sustainability status of integrated waste management in TPST-Bantargebang among stakeholders is very diverse, on average the multidimensional index values range at 51.71 at a 97 percent determination level and produce 15 sensitive attributes that affect the integrated waste management at TPST-Bantargebang. In conclusion, overall the sustainability status of integrated waste management in TPST-Bantargebang is included in the sustainable category (pass).
\end{abstract}

Keywords: Multi-dimensional scalling, Integrated waste management, R statistics, TPST Bantargebang

Citation: Sukwika, T., dan Noviana, L. (2020). Status Keberlanjutan Pengelolaan Sampah Terpadu di TPST-Bantargebang Bekasi: Menggunakan Rapfish dengan R Statistik. Jurnal Ilmu Lingkungan, 18(1), 107-118, doi:10.14710/jil.18.1.107-118

\section{Pendahuluan}

TPST Bantargebang di kota Bekasi, Jawa Barat selama ini digunakan untuk menampung buangan sampah dari wilayah Jakarta, sejak tahun 1989. TPA Bantargebang tersebut dikelola oleh Pemda DKI Jakarta dengan menerapkan konsep pengelolaan tempat pengolahan sampah terpadu (TPST). Secara kepemilikan aset, lahan TPA seluas 115 ha Bantargebang sudah menjadi aset milik pemerintah provinsi (pemprov) Daerah Khusus Ibukota (DKI) Jakarta sejak tahun 1999. Secara teknis, pelaksanaan pengelolaan persampahan dilakukan melalui skema kerjasama antara pemprov DKI Jakarta dengan pemerintah kota (pemkot) Bekasi. Dasar hukum terkait kerjasama tersebut tertuang dalam dokumen 107 addendum ke-3 keputusan kerjasama nomor 96 tahun 1999 junto nomor 3428/072 tahun 2003 dan nomor 168 tahun 1999 junto nomor 658.1/Kep.439 tahun 2003 tentang pengelolaan sampah dan TPA sampah di kecamatan Bantargebang kota Bekasi (DKI-Jakarta, 2003).

Volume sampah dari Jakarta ke TPST Bantargebang rata-rata sekitar 7.000 sampai 8.000 ton per hari yang dilayani oleh 1.200 truk sampah, dimana $60 \%$ diantaranya merupakan sampah domestik atau rumah tangga. Kondisi saat ini, daya tampung sampah dari Bekasi maupun Jakarta sudah mendekati maksimum dan beberapa tahun ke depan, sampah tidak dapat lagi dibuang di TPST Bantargebang. Bahkan diperkirakan, TPST 
Sukwika, T., dan Noviana, L. (2020). Status Keberlanjutan Pengelolaan Sampah Terpadu di TPST-Bantargebang Bekasi: Menggunakan Rapfish dengan R Statistik. Jurnal IImu Lingkungan, 18(1), 107-118, doi:10.14710/jil.18.1.107-118

Bantargebang akan tutup pada 2021. Di beberapa zona TPST yang belum dikelola dengan baik, masih menggunakan sistem open dumping, menyebabkan kerusakan lingkungan karena menghasilkan air lindi (leachate) dan gas metana.

Seiring berjalannya waktu, meskipun dinas kebersihan DKI Jakarta sudah memiliki lahan untuk TPA, namun dalam penanganan sampahnya masih dilakukan upaya optimal. Bahkan sejak diberlakukannya undang-undang pengelolaan sampah (Indonesia, 2008), upaya-upaya perbaikan untuk pengelolaan TPA yang lebih efektif terus dilakukan hingga sampai saat ini. Di TPST Bantargebang, permasalahan yang krusial adalah daya tampung yang terus menyusut, dimana kapasitas maksimum adalah 49 juta ton, kini tinggal tersisa kapasitas 10 juta ton (UPTPST, 2020). Begitu juga pengelolaan sampah dengan open dumping sudah melampaui ketinggian 35 meter. Jarak efektif polusi udara (bau) mencapai $10 \mathrm{~km}$ dari titik TPST. Permasalahan daya tampung TPST ini menurut Manurung et al. (2016), bisa didekati dengan dua acara yaitu melalui program intensifikasi, seperti program yang dijalankan dengan menggunakan teknologi yang dapat mereduksi sampah; dan ekstensifikasi, misalnya perluasan lahan TPST Bantargebang eksisting dengan lahan baru di sekitar lahan yang sudah ada.

Merespon permasalahan sosial dan lingkungan di atas, pemerintah daerah DKI Jakarta mengubah konsep pengelolaan TPST menjadi bernilai ekonomi dan bernilai tambah. Komitmen pemprov DKI Jakarta akan mengubah pengolahan sampah di TPST Bantargebang, yaitu tidak lagi menggunakan sistem open dumping dan sanitary landfill atau menimbun sampah menggunakan tanah merah, lalu menutupnya menggunakan geomembrane. Namun lebih inovatif, yaitu memakai sistem landfill mining (menambangan gas metana dari sampah), dengan tujuan mereduksi sampah yang sudah tertimbun pada zona landfill, lalu sampah tersebut dimanfaatkan kembali. Sistem ini juga dapat meningkatkan kapasitas penimbunan sampah di zona, memulihkan (recovery) material agar dapat dimanfaatkan kembali, hingga memperoleh suatu lahan baru.

Tidak hanya itu, sampah yang telah dikeruk berpotensi diolah menjadi sumber energi baru (bahan bakar alternatif) atau refuse derived fuel (RDF). Selanjutnya, berdasarkan dokumen kerjasama MoU/PKS antara pemprov DKI Jakarta dengan BPPT pada 20 Desember 2017, telah membangun pilot project berupa pembangkit listrik tenaga sampah (PLTSa) di dalam area TPST Bantargebang. PLTSa dibangun dengan kapasitas 50-100 ton sampah per hari yang direncanakan menghasilkan listrik sebesar $400 \mathrm{kWh}$. PLTSa ini mengolah sampah yang dihasilkan langsung oleh masyarakat (fresh waste). Hasil perhitungan Hermawan (2017) diketahui bahwa, potensi kapasitas daya listrik yang dihasilkan dari pengolahan sampah sebesar 2.110,69 Ton/hari dapat menghasilkan 41.580,61 kW. Dalam mengurangi timbulan sampah, manajemen TPST Bantargebang membuat rumah composting dan membentuk bank sampah yang bekerja sama dengan lembaga peduli lingkungan. Kegiatan pengelolaan limbah berbasis masyarakat akan diminati jika dibentuk juga kesiapan sistem pasar limbahnya, hal ini penting untuk memastikan pendapatan dari penjualan produk daur ulang dan kompos yang dihasilkan oleh masyarakat terjamin (Aprilia, 2016).

Menyikapi persoalan kondisi di atas, Pemprov DKI Jakarta telah merealisasikan sebagian dari rencana tiga paket kebijakan strategis penanganan sampah, yaitu (1) menekan atau mengurangi sampah dari sumber hulunya, baik dari rumah, kantor, pasar hingga hotel dan sebagiannya (DKI-Jakarta, 2013, 2016a, 2016b, 2017; Indonesia, 2008, 2010); (2) menyediakan intermediate treatment facility (ITF) atau fasilitas pengolahan sampah di dalam wilayah DKI Jakarta (DKI-Jakarta, 2016c), efektif digunakan tahun 2021; dan (3) membangun pembangkit listrik tenaga sampah (PLTSa) (Dirjen-Cipta-Karya, 2012; Indonesia, 2018), efektif digunakan tahun 2019. Dengan adanya kebijakan strategis dalam penanganan sampah ini diharapkan ke depan pemprov DKI Jakrta dapat mengelola sampah dengan baik bahkan bisa mengurangi volume sampah. Keberhasilan metode inovatif pengelolaan sampah oleh pemprov DKI Jakarta sangat penting dan menjadi harapan kita semua. Untuk itu, dibutuhkan kesadaran seluruh stakeholder agar terlibat dalam pengurangan sampah secara mandiri baik di daerah pemukiman, kawasan komersial dan tempat lainnya. Upaya pengurangan sampah dengan pendekatan 3R (reduce, reuse, recycle) terus dikembangkan meskipun masih terbatas dan memerlukan upaya berkelanjutan. Oleh karena itu, menurut Winahyu et al. (2013), pemerintah perlu mendorong dan mengoptimalkan bisnis daur ulang memperbaikan sistem teknologi pengolahan sampah yang berkelanjutan. Tantangan lainnya adalah belum optimalnya kelembagaan pengelola sampah, baik sebagai regulator maupun sebagai operator.

Keberadaan TPST Bantargebang masih dinilai tetap menimbulkan dampak sosial bagi masyarakat dan lingkungan sekitarnya. Untuk menyikapi hal ini, Pemprov DKI Jakarta mengubah kebijakan, bahwa TPST tidak lagi hanya berfungsi untuk melayani kebutuhan masyarakat (service center) dalam hal pengolahan sampah. Namun kini, peran TPST sudah diperhitungkan manfaat atau nilai tambah (added value) yang dapat dihasilkan dari sampah.

Dalam pengelolaan sampah, TPST Bantargebang menerapkan konsep yang lebih ramah lingkungan, terpadu, dan berkelanjutan (UPTPST, 2020). Namun di lain sisi, persepsi negatif sebagian masyarakat dan pemangku kepentingan (stakeholder) terkait isu lingkungan dan sosial dari masih ada. Untuk itu, perlu 
dilakukan sebuah kajian terkait model keberlanjutan pengelolaan sampah terpadu oleh pemprov DKI Jakarta di TPST Bantargebang Bekasi. Pada studi ini, ada enam aspek sebagai dimensi keberlanjutan, yaitu: dimensi teknik pengolahan, ekonomi dan bisnis, kesejahteraan sosial, regulasi dan kelembagaan, manajemen lingkungan, dan produsi bersih. Tujuan penelitian ini adalah mengevaluasi status keberlanjutan pengelolaan sampah terpadu di TPST Bantargebang.

\section{Metodologi}

\subsection{Tempat dan Waktu Penelitian}

Penelitian lapangan secara intensif dilaksanakan di pengelolaan tempat pengolahan sampah terpadu (TPST) Bantargebang Kelurahan Ciketing Udik, Kelurahan Cikiwul dan Kelurahan Sumur Batu, Kecamatan Bantargebang Kota Bekasi, selama bulan Agustus - Desember 2019.

\subsection{Metode Pengumpulan Data}

Data yang dikumpulkan meliputi data primer dan data sekunder. Data primer dihimpun dari wawancara pakar yang diperoleh melalui metode snowball. Tujuan dari teknis sampling snowball ini meningkatkan jumlah responden dalam prosesnya guna mencapai hasil yang akurat dan membangun gagasan berdasarkan sumbersumber dari jaringan yang terbentuk (Salganik \& Heckathorn, 2007). Teknik sampling snowball dimulai dengan informasi yang terbatas dari responden awal hingga akhirnya informasi berkembang luas dan mendalam (Nurdiani, 2014). Data lapangan yang diperoleh melalui informan, responden, dokumentasi atau observasi (Widodo \& Mukhtar, 2000). Data sekunder diperoleh dari laporan, jurnal maupun hasil-hasil kajian dari berbagai instansi terkait, baik yang berlokasi di tempat penelitian maupun di luar lokasi penelitian.

\subsection{Metode Teknik Analisis}

Teknik analisis yang digunakan dalam penelitian ini menggunakan teknik multi-dimensional scalling (MDS) Rapfish (T. Pitcher et al., 2013) yang diintegrasikan ke dalam perangkat lunak R statistics (Orland \& Varkey, 2014). MDS dikembangkan oleh T. J. Pitcher dan Preiksho (2001) sebagai alat untuk mengevaluasi keberlanjutan perikanan, yang dikenal sebagai rapfish dan dikembangkan lebih lanjut untuk berbagai bidang seperti kehutanan rakyat (Sukwika et al., 2016, 2018), reservoir (Kholil et al., 2015), dan industry estate (Wikaningrum, 2015). Pengklasifikasian MDS dibuat berdasarkan kesamaan data, baik yang bersifat kualitatif (nonmetric) dan kuantitatif disebut dengan (metric).

Proses analisis RAP-Multidimensi dalam penelitian ini dilakukan melalui beberapa tahapan yakni: (1) penentuan atribut dimensi-dimensi untuk mengevaluasi teknis pengelolaan sampah terpadu di TPST Bantargebang melalui studi literatur terdahulu
(Tabel 2), (2) penilaian atribut dalam skala ordinal berdasarkan kriteria keberlanjutan dimensi, (3) Analisis data menggunakan teknik rapfish dengan menggunakan software R statistik (T. Pitcher et al., 2013), (4) mengkaji nilai indeks dan status keberlanjutan dimensi-dimensi, lihat Tabel 1 (Orland \& Varkey, 2014), (5) mengkaji atribut yang sensitif berpengaruh terhadap keberlanjutan dengan menggunakan sensitivity analysis (laverage analysis), (6) mengkaji pengaruh kesalahan dalam perhitungan dengan menggunakan analisis Monte Carlo, dan (7) memetakan hasil analisis MDS ke dalam diagram layang-layang.

Tabel 1. Kategori nilai indeks MDS

\begin{tabular}{lll}
\hline Nilai Indeks & Indikasi & Status \\
\hline $0,00-40,00$ & Gagal (Fail) & Tidak Berkelanjutan \\
$40,01-70,00$ & Lulus (Pass) & Berkelanjutan \\
$70,01-100,00$ & Baik (Good) & Sangat Berkelanjutan \\
\hline
\end{tabular}

Sumber: diadopsi dari Orland dan Varkey (2014)

Dalam metode standar, skor diberikan pada skala nol hingga sepuluh (10 atau 0 mewakili Baik atau Buruk). Selama ini penggunaan skala yang dipergunakan berbeda-beda (mis. dari nol hingga 3 atau 5), tetapi belakangan ini penggunaan skala nol hingga 10 telah menjadi standar FAO Code of Conduct tentang pengelolaan perikanan yang baik (RAPFISH, 2011).

Tabel 2. Dimensi dan atribut penelitian

\begin{tabular}{|c|c|}
\hline Dimensi & Atribut \\
\hline [1] Teknik & 1.1 Insinerator; 1.2 Komposting; 1.3 Open \\
\hline Pengelolaan & $\begin{array}{l}\text { Dumping; } 1.4 \text { Sanitary Landfill; } 1.5 \text { Landfill } \\
\text { Mining. }\end{array}$ \\
\hline [2] Regulasi \& & 2.1 Kerjasama Lintas Lembaga; 2.2 \\
\hline Kelembagaan & $\begin{array}{l}\text { Kerjasama Parapihak Konflik; } 2.3 \text { Sarana } \\
\text { Prasarana; } 2.4 \text { Kebijakan Tataruang TPA; } \\
\text { 2.5 Kebijakan Daya Dukung Lingkungan. } \\
\text { 2.6 LSM Peduli Lingkungan; } 2.7 \text { Efektifitas; } \\
\text { Regulasi; 2.8 Kapasitas Manajemen SDM. }\end{array}$ \\
\hline [3] Manajemen & 3.1 Kelompok Pengumpul Barang Bekas; \\
\hline Lingkungan & $\begin{array}{l}\text { 3.2 Kesesuaian Tataruang TPA; } 3.3 \\
\text { Dayatampung Sampah TPA; } 3.4 \text { Bank } \\
\text { Sampah RW; 3.5 Pengurangan Sampah } \\
\text { Rumah-tangga; 3.6 Pemilahan Jenis } \\
\text { Sampah; 3.7 Minimisasi Cemaran Buangan } \\
\text { Sampah; 3.8 Jadwal Pengangkutan Sampah. }\end{array}$ \\
\hline [4] Ekonomi \& & 4.1 Prospek Bisnis Daur Ulang; 4.2 Bank \\
\hline Bisnis & $\begin{array}{l}\text { Sampah; } 4.3 \text { Investor 3R; } 4.4 \text { PAD Bekasi; } \\
\text { 4.5 Pendapatan Rumahtangga; } 4.6 \text { Nilai } \\
\text { Ekonomi Barang Bekas; } \\
\text { Ketergantungan TPA Bantuan Subsidi. }\end{array}$ \\
\hline [5] Sosial & 5.1 Alternatif Pekerjaan Pemulung; 5.2 \\
\hline Kesejahteraan & 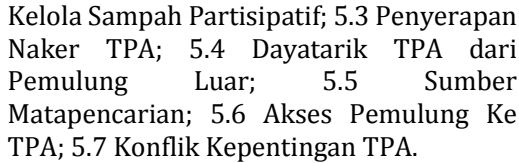 \\
\hline $\begin{array}{l}\text { [6] Produksi } \\
\text { Bersih }\end{array}$ & $\begin{array}{l}\text { 6.1 IPAS; } 6.2 \text { PLTSa; } 6.3 \text { Daur Ulang; } 6.4 \\
\text { Sampah Organik; } 6.5 \text { Sampah Anorganik; } \\
\text { 6.6 Sampah B3. }\end{array}$ \\
\hline
\end{tabular}

\section{Hasil dan Pembahasan}

Evaluasi penilaian status keberlanjutan terhadap pengelolaan sampah terpadu dari kawasan Jakarta di TPST-Bantargebang kota Bekasi dianalisis berdasarkan data yang dihimpun dari para pemangku 
kepentingan (stakeholders) yang mewakili secara kelembagaan yaitu Unit pengelola sampah terpadu dinas lingkugan hidup DKI Jakarta (UPST-DLH-DKIJ), Knowledge greeneration foundation (GreenerationNGO), Sustainable Indonesia (Sustainable-ID), Kelompok pengusaha bank sampah (Bank-Sampah), Satuan tugas lingkungan hidup lintas wilayah (SatgasLH), dan Yayasan waste for change (Wast4Change).

\subsection{Evaluasi Status keberlanjutan MDS TPST}

Evaluasi dari Rap-TPST (modifikasi MDS Rapfish) menggunakan $\mathrm{R}$ statistic menunjukkan secara keseluruhan bahwa, indeks keberlanjutan TPST (Pengelolaan Tempat Pengolahan Sampah Terpadu) di Bantargebang Kota Bekasi untuk enam dimensi adalah 51,71 (cukup berkelanjutan). Berdasarkan Tabel 3 terlihat bahwa dimensi teknik pengelolaan sampah di TPST-Bantargebang kota Bekasi memiliki nilai indeks keberlanjutan sebesar 68,66. Nilai tersebut merupakan paling tinggi dibandingkan dengan lima dimensi keberlanjutan lainnya.

Tabel 3. Analisis Keberlanjutan: MDS, MC, R²

\begin{tabular}{llcc}
\hline \multirow{2}{*}{\multicolumn{1}{c}{ Dimensi }} & \multicolumn{2}{c}{$\begin{array}{c}\text { Kilai Indeks } \\
\text { Keberlanjutan }\end{array}$} & $\begin{array}{c}\text { Koefisien } \\
\text { Determinasi }\end{array}$ \\
\cline { 2 - 3 } & $\begin{array}{c}\text { MDS } \\
\text { in R }\end{array}$ & $\begin{array}{c}\text { Monte } \\
\text { Carlo }\end{array}$ & $\mathrm{R}^{2}$ \\
\hline Multidimensional & 51,71 & 51,71 & 0,9657 \\
Teknik Pengelolaan & 68,66 & 68,66 & 0,9756 \\
Ekonomi Bisnis & 54,33 & 54,33 & 0,9685 \\
Kesejahteraan Sosial & 57,15 & 57,15 & 0,9659 \\
Regulasi Kelembagaan & 56,86 & 56,86 & 0,9738 \\
Manajemen Lingkungan & 50,02 & 50,02 & 0,9775 \\
Produksi Bersih & 59,21 & 59,21 & 0,9687 \\
\hline
\end{tabular}

Analisis simulasi Monte Carlo (MC) merupakan analisis lanjutan dalam analisis Rap-TPST dengan metode multidimensional (MDS in $R$ statistic) untuk mengetahui dan mengevaluasi dampak kesalahan acak (random error) dari tiap atribut yang digunakan untuk melihat sebuah kondisi keberlanjutan. Simulasi MC dapat mengevaluasi dampak kesalahan acak pada analisis statistik yang dilakukan untuk semua dimensi (Farrance \& Frenkel, 2014; Kavanagh \& Pitcher, 2004). Pendekatan analisis metode MC dapat berkontribusi pada peningkatan keandalan hasil secara akurat dan memperkirakan keakuratan analisis ketidakpastian (Kim et al., 2016).

Hasil analisis MC tidak memiliki nilai perbedaan atau tidak ada selisih antara indeks keberlanjutan yang dihasilkan oleh nilai MDS dan MC. Hal itu ditunjukkan dengan berkumpulnya titik hasil pengulangan MDS pada titik yang sama atau titik ordinasi berada pada posisi yg sangat berdekatan. Hasil MC berkategori baik (tidak memiliki rentang kesalahan yang signifikan), hal tersebut mengindikasikan bahwa kesalahan dalam pembuatan skor setiap atribut relatif kecil, keragaman pemberian skor akibat perbedaan opini relatif sangat kecil, kesalahan dalam pemasukan data dapat dihindari.

Analisis MC yang dilakukan pada atribut dimensi Teknik Pengolahan menunjukkan stabilitas dari hasil analisis Rap-TPST ordination dan leverage of atributes dengan iterasi sebanyak 25 kali. Pada Gambar 1, 2, 3, 4, 5, dan 6 terlihat, tidak ada perbedaan atau perubahan posisi plot atribut baik pada hasil perhitungan MDS maupun uji validitas MC. Ini berarti bahwa model analisis MDS memadai untuk memperkirakan nilai indeks pengelolaan sampah terpadu di TPST Bantargebang. Nilai validitas yang kecil apalagi nol menunjukkan kesalahan dari akuisisi dan analisis data minimal, dan tidak membahayakan hasil dari penelitian ini (Sukwika et.al 2016).

\section{a. Dimensi Teknik Pengolahan}

Ordinasi status keberlanjutan memberikan ilustrasi tentang status keberlanjutan setiap dimensi sesuai dengan skor dari atribut-atributnya. Posisi nilai indeks status keberlanjutan diilustrasikan pada sumbu axis (x), sedangkan variasi skor dari atributatribut yang telah di telaah diilustrasikan pada sumbu ordinat (y) (Kavanagh \& Pitcher, 2004; Sukwika et al., 2016). Indeks hasil ordinasi untuk status keberlanjutan pengelolaan sampah terpadu di TPST Bantargebang pada dimensi Teknik Pengelolaan, secara keseluruhan adalah 68,66 \% atau pada kategori cukup baik karena nilai indeks dimensi Teknik Pengelolaan masuk ke dalam range 50,0175,00 (cukup berkelanjutan).

Berdasarkan pemantauan di lapangan, teknik pengelolaan sampah di TPST-Bantargebang sudah baik. Proses yang dilakukan mulai perataan dan pemadatan dengan alat berat, penutupan tanah (landfill) harian setebal $20 \mathrm{~cm}$. Bahkan, jika ketinggian sampah mencapai $5 \mathrm{~m}$, landfill menjadi $20 \mathrm{~cm}$. Proses lanjutan lainnya yaitu terasering/countering landfill, IPAS, dan power house gas metana. Teknis sanitary landfill, disebutkan Khulaemi (2010) yaitu landfill ditutup dengan geomembrane sehingga menghasilkan gas methane $\left(\mathrm{CH}_{4}\right)$ dan kemudian disalurkan ke gas engine (diesel) di power plant yang berkapasitas 3 Mega watt (MW) dan tegangan 400 volt .

Pengerjaan melalui sistem pengolahan sampah tersebut diatas, mendorong dimensi teknik pengolahan ini akan berkelanjutan ke depannya. Status keberlanjutan dimensi Teknik Pengolahan disajikan pada Gambar 1. Indeks hasil ordinasi untuk status keberlanjutan.

Proses penentuan ordinasi memungkinkan terjadi kesalahan acak yang disebabkan oleh beberapa faktor berikut ini (Brancato et al., 2006; Peres-Neto et al., 2003): 1) kesalahan dalam skoring akibat minimnya informasi; 2) variasi dalam skoring akibat perbedaan penilaian; dan 3) kesalahan dalam memasukkan data. Oleh karena itu, dilakukan uji ordinasi menggunakan simulasi Monte Carlo untuk mengetahui dampak kesalahan acak (random error). Simulasi Monte Carlo dilakukan dengan metode "scatter plot".

Hasil simulasi Monte Carlo (triangular) dimensi Teknik Pengelolaan dilakukan sebanyak 25 kali 
iterasi, menurut Goldstein et al. (2019) dengan pengulangan 25 kali telah diperoleh penyimpangan kecil yang artinya semakin valid) dan dengan selang kepercayaan 97\% (artinya secara kaidah statistik terdapat pertimbangan plus/minus error yang kecil, yakni 3\%). Hasil simulasi monte carlo untuk dimensi Teknik Pengelolaan menunjukkan hasil rata-rata sebesar 68,66\%. Jika dibandingkan dengan hasil ordinasi nampak tidak ada perbedaan yang signifikan.
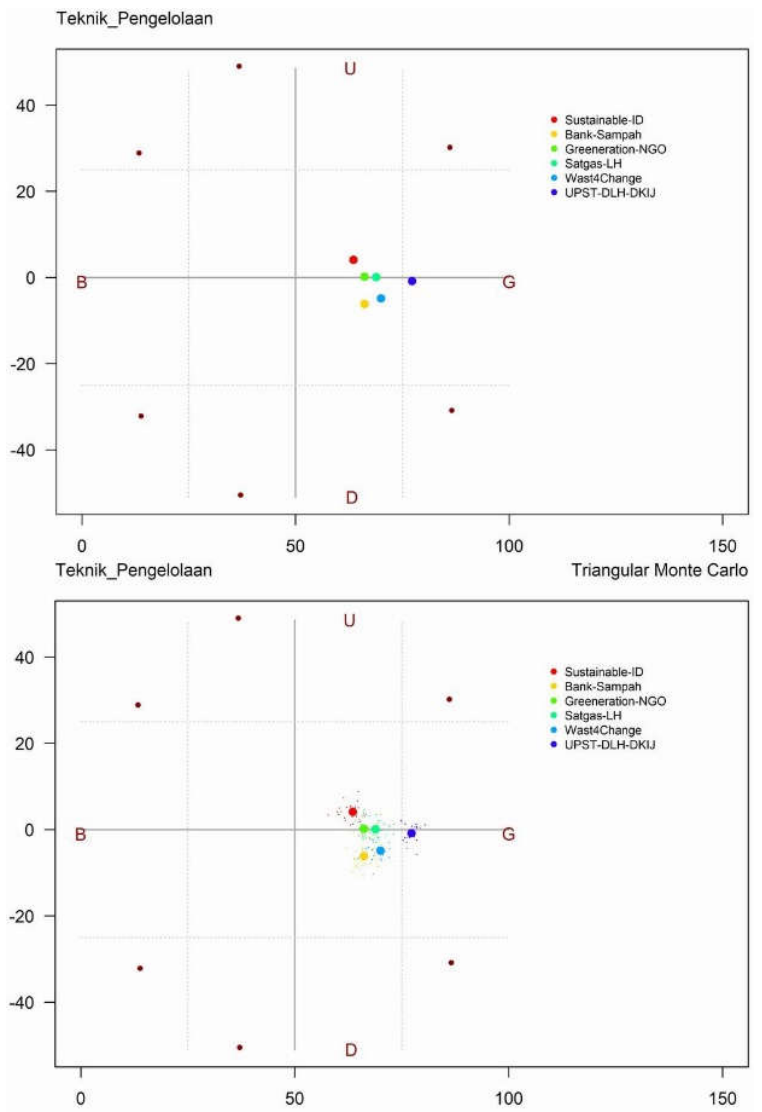

Gambar 1. Diagram indeks keberlanjutan multidimensional teknik pengelolaan

\section{b. Dimensi Ekonomi dan Bisnis}

Indeks hasil ordinasi untuk status keberlanjutan pengelolaan sampah terpadu di TPST Bantargebang pada dimensi Ekonomi Bisnis, secara kelesuruhan adalah $54,33 \%$ atau pada kategori cukup baik. Status keberlanjutan dimensi Ekonomi Bisnis disajikan pada Gambar 2. Indeks hasil ordinasi untuk status keberlanjutan. Hasil simulasi Monte Carlo (triangular) untuk dimensi Ekonomi Bisnis dilakukan sebanyak 25 kali pengulangan dengan selang kepercayaan 96\% (artinya secara kaidah statistik terdapat pertimbangan plus/minus error yang kecil, yakni 4\%). Hasil simulasi monte carlo untuk dimensi Ekonomi Bisnis sebesar 54,33\%. Jika dibandingkan dengan hasil ordinasi nampak tidak ada perbedaan yang signifikan.

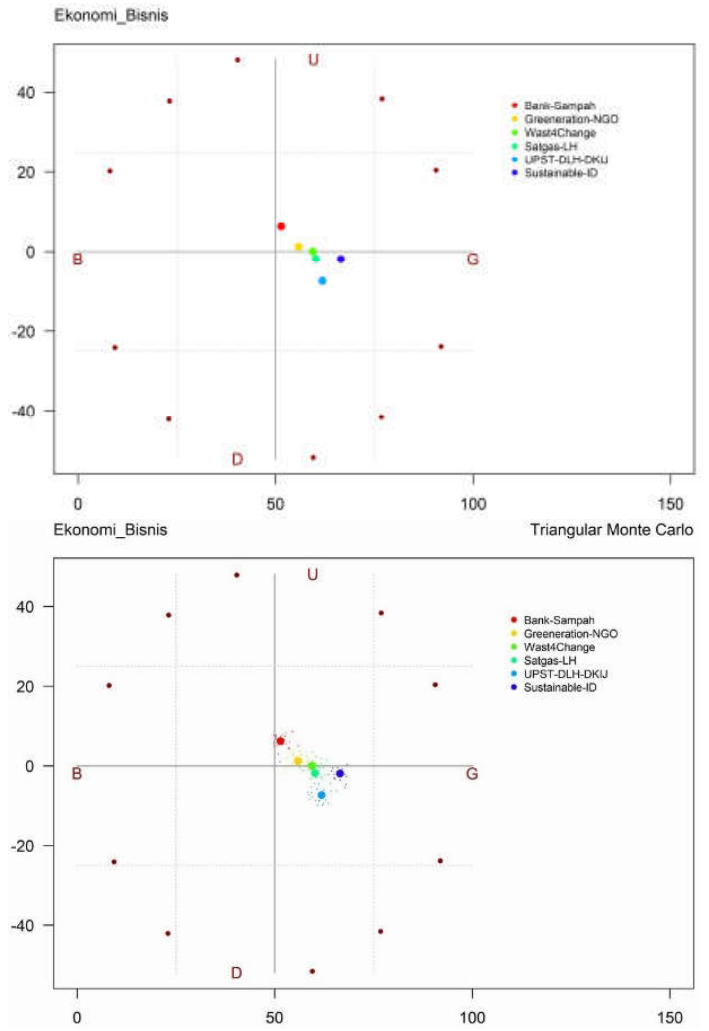

Gambar 2. Diagram indeks keberlanjutan multidimensional ekonomi bisnis

Pembongkaran sampah dari truk ke titik buang secara estafet. Sampah organik di-unloading di titik pengolahan kompos. Tahapan composting yang dilakukan di TPST-Bantargebang mulai dari area receiving, mixer dan crusher, granulator, rotary dryer dan collier, dan diakhiri dengan packing. TPSTBantargebang mempunyai lahan composting seluas 2 hektar yang terdiri dari areal kompos dan urban farming. Industri composting mampu menghasilkan 30 ton kompos powder sampah organik per hari (UPTPST, 2020). Secara ekonomi, pengolahan sampah organik menjadi kompos dapat memberikan side income yang lumayan (Darwati \& Anggraini, 2012).

\section{c. Dimensi Kesejahteraan Sosial}

Indeks hasil ordinasi untuk status keberlanjutan pengelolaan sampah terpadu di TPST Bantargebang pada dimensi Kesejakteraan Sosial, secara kelesuruhan adalah 57,15\% atau pada kategori cukup baik. Status keberlanjutan dimensi Kesejakteraan Sosial disajikan pada Gambar 3. Indeks hasil ordinasi untuk status keberlanjutan.

Setiap harinya sampah yang masuk ke TPSTBantargebang dari DKI Jakarta sekitar 7.000 ton dan lebih dari 7.000 pemulung bergantung pada tumpukan sampah anorganik. Sampah organik yang sering dipilah adalah sampah plastik, kertas, dan sampah campuran lain (Handayani et al., 2009). Sebagai tanggungjawab social, pemerintah DKI memberikan jaminan kesehatan BPJS kepada para pemulung (UPTPST, 2020). 

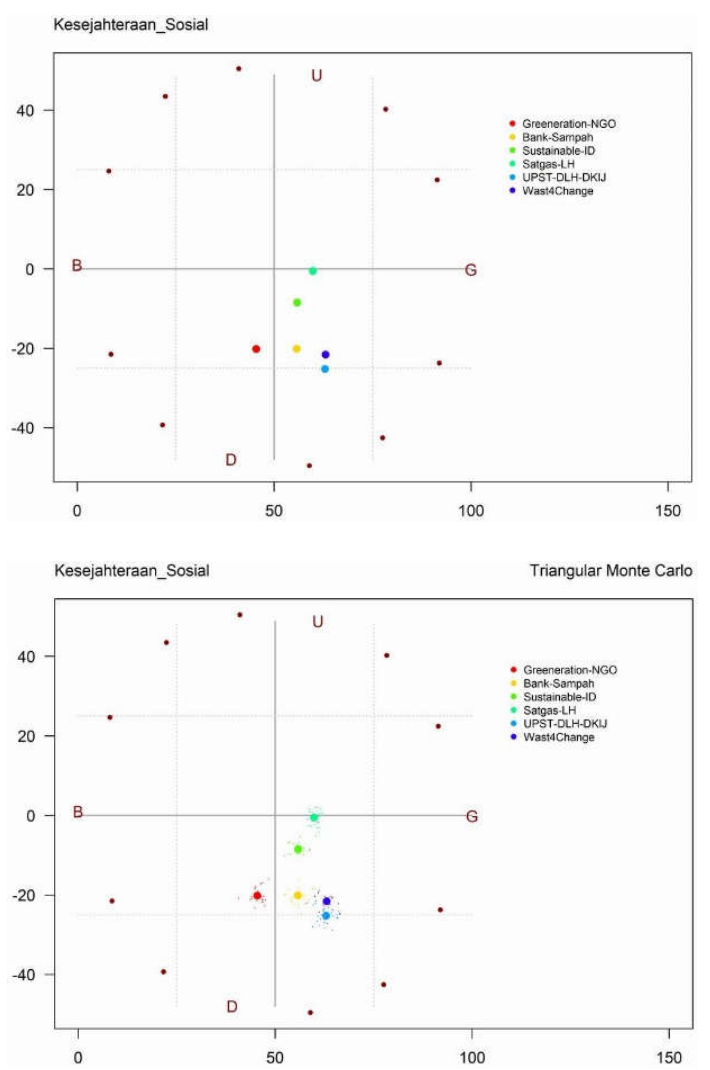

Gambar 3. Diagram indeks keberlanjutan multidimensional kesejahteraan sosial

\section{d. Dimensi Regulasi dan Kelembagaan}

Indeks hasil ordinasi untuk status keberlanjutan pengelolaan sampah terpadu di TPST Bantargebang pada dimensi Regulasi Kelembagaan, secara kelesuruhan adalah 56,86\% atau pada kategori cukup baik.

Status keberlanjutan dimensi Regulasi Kelembagaan disajikan pada Gambar 4. Indeks hasil ordinasi untuk status keberlanjutan. Hasil simulasi Monte Carlo (triangular) untuk dimensi Regulasi Kelembagaan dilakukan menunjukkan hasil rata-rata sebesar 56,86\% dengan selang kepercayaan 97\%.

Dari 110,3 Ha area TPST sekitar 18,09\% untuk prasarana dan sarana seperti jalan masuk, jalan kantor, workshop composting, areal pencucian kendaraan operasional, instalasi pengolahan lindi, penambangan sampah, pembangkit listrik tenaga sampah, dan RTH. Kerjasama lintas lembaga seperti sektor swasta dan masyarakat peduli lingkungan telah mendorong peningkatkan kualitas pelayanan publik, secara transparan, efisien dan bertanggungjawab (Aditya, 2014; Moruff, 2012; A. Mulasari et al., 2016; Widianto, 2007) oleh DHL DKI Jakarta. Komunitas masyarakat peduli lingkungan menjadi driven factor dalam mengedukasi timbulan sampah dan mensosialisasikan regulasi di tingkat lokal (Aditya, 2014; Ronasifah et al., 2019). Masalah dampak lingkungan seringkali berakibat pada timbulnya konflik parapihak. Upaya yang dilakukan oleh pemprov DKI Jakarta adalah membangun teknologi pengolahan sampah ramah lingkungan seperti intermediate treatment facility (Hermawan, 2017; Mulyadin et al., 2018).

Hasil simulasi Monte Carlo (triangular) untuk dimensi Kesejakteraan Sosial dilakukan sebanyak 25 kali pengulangan dengan selang kepercayaan 96\%. Hasil simulasi monte carlo untuk dimensi Kesejakteraan Sosial menunjukkan hasil rata-rata sebesar $57,15 \%$.

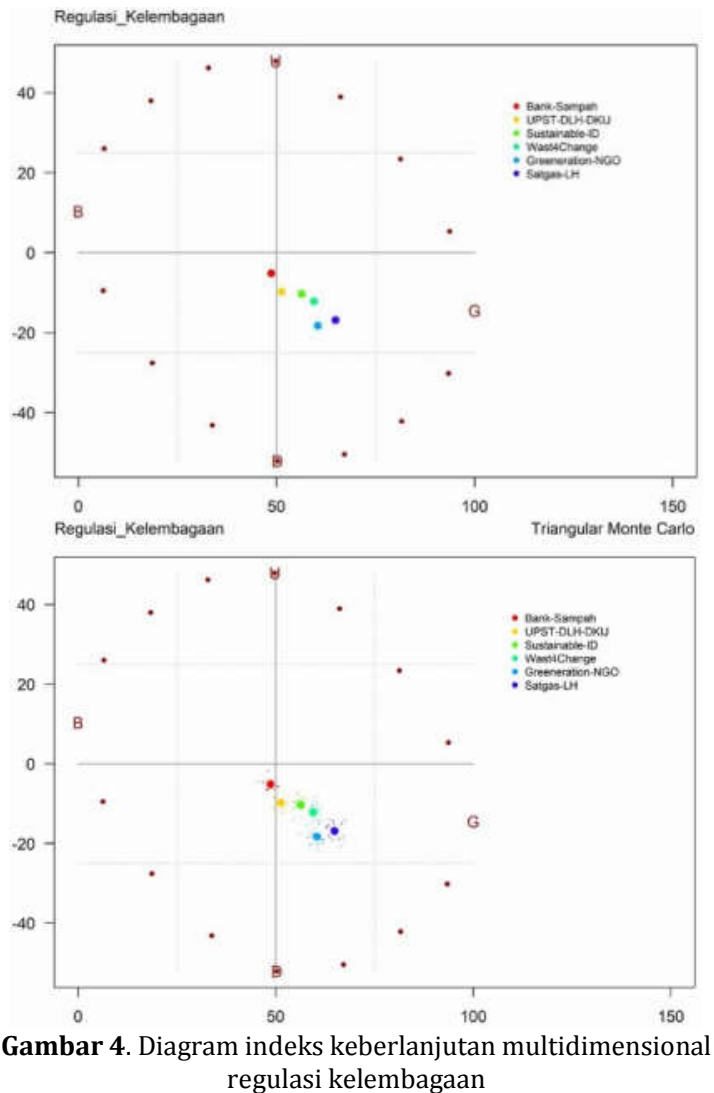

\section{e. Dimensi Manajemen Lingkungan}

Indeks hasil ordinasi untuk status keberlanjutan pengelolaan sampah terpadu di TPST Bantargebang pada dimensi Manajemen Lingkungan sebesar $50,02 \%$ (kategori cukup baik). Indeks hasil ordinasi untuk status keberlanjutan. begitu juga nilai yang sama diperoleh dari hasil simulasi Monte Carlo (triangular) dengan selang kepercayaan 97\%. Jika dibandingkan dengan hasil ordinasi nampak tidak ada perbedaan yang signifikan. Status keberlanjutan dimensi Manajemen Lingkungan disajikan pada Gambar 5.

Jumlah keberadaan bank sampah di DKI Jakarta sebanyak 1.500 unit dan kota Bekasi 300 unit. Peran partisipasi pemulung dalam pemilahan sampah sangat penting. Integrasi bank sampah dalam pengelolaan sampah dapat memberikan peningkatan kesejahteraan warga (Asteria \& Heruman, 2016; Anih Sri Suryani, 2014). Keberhasilan sistem integrasi tersebut berguna bagi pengambilan keputusan dalam pengalokasian sumber daya dan membuat perencanaan keberlanjutan proses manajemen sampah (Asteria \& Heruman, 2016; Kristina, 2014). 

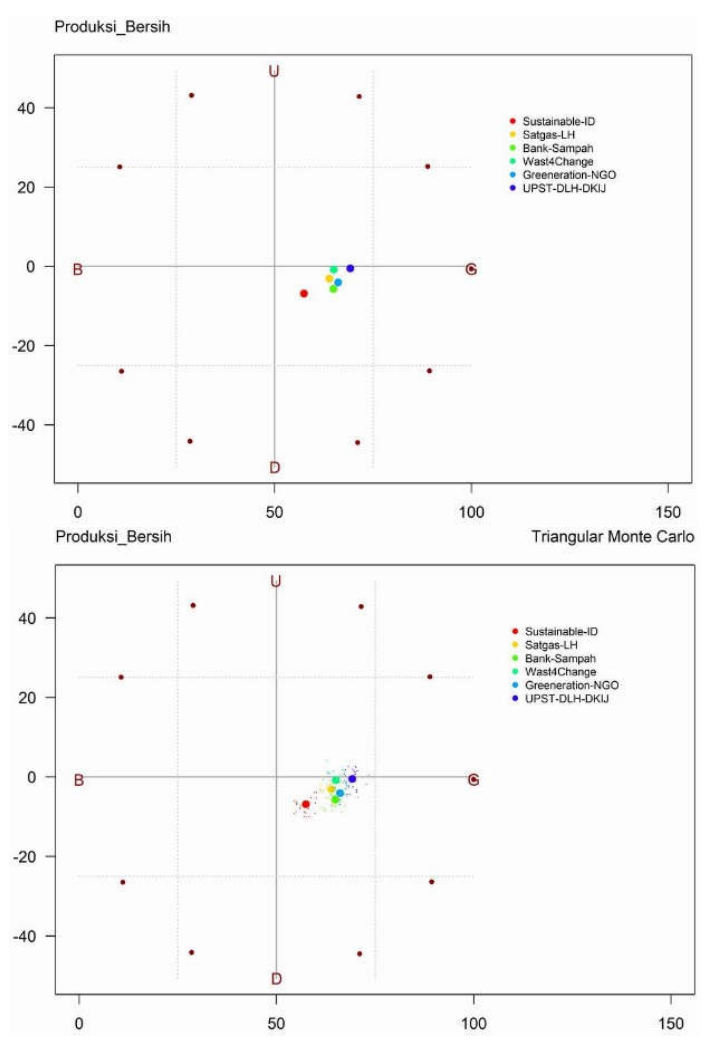

Gambar 5. Diagram indeks keberlanjutan multidimensional produksi bersih

\section{f. Dimensi Produksi Bersih}

Indeks hasil ordinasi untuk status keberlanjutan pengelolaan sampah terpadu di TPST Bantargebang pada dimensi Produksi Bersih, secara kelesuruhan adalah 59,21\% atau pada kategori cukup baik.

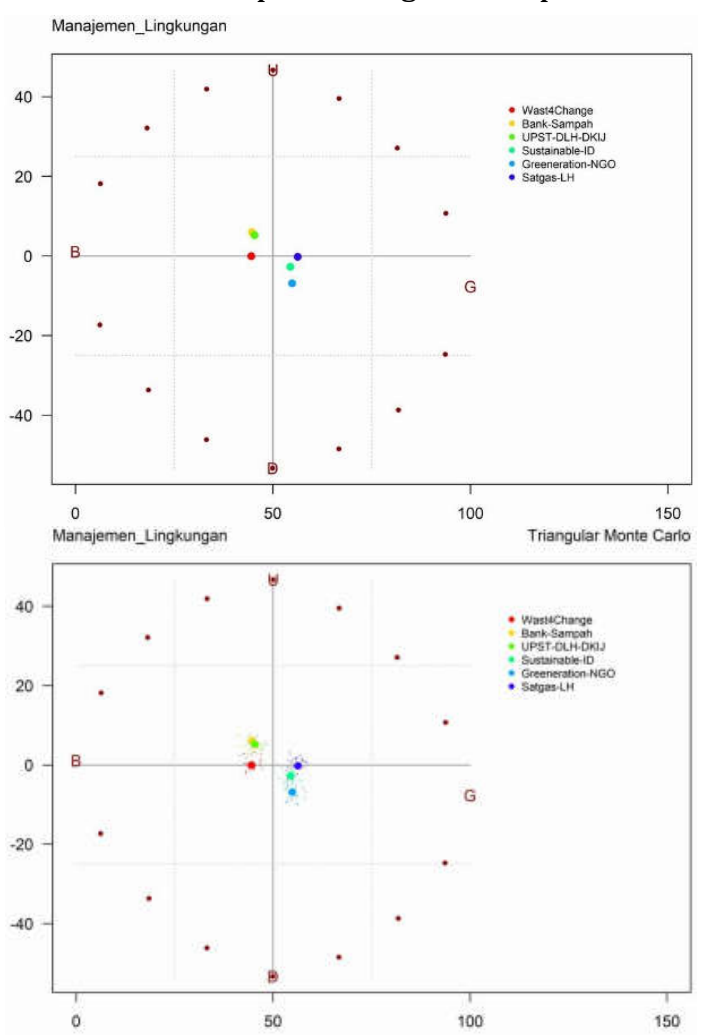

Gambar 6. Diagram indeks keberlanjutan multidimensional manajemen lingkungan
Pengurangan volume sampah dapat dilakukan dengan cara memilah dan mengolah sampah organik dan anorganik dari sumber sampah dengan sistem 3R (reuse, reduce, recycle) (Sudirman, 2012). Kegiatan pengelolaan limbah akan diminati jika sistem pasar limbahnya dipersiapkan, hal ini penting untuk memastikan pendapatan dari penjualan produk daur ulang dan kompos yang dihasilkan oleh masyarakat terjamin (Aprilia, 2016). Menurut UPTPST (2020) penambahan prasarana IPAS setiap dilakukan landfill mining di zona tersebut.

Status keberlanjutan dimensi Produksi Bersih disajikan pada Gambar 6. Indeks hasil ordinasi untuk status keberlanjutan. Hasil ordinasi dimensi Produksi Bersih nampak tidak ada perbedaan yang signifikan dengan hasil simulasi Monte Carlo (triangular) yaitu sebesar 59,21\% dengan selang kepercayaan 96\%.

\subsection{Analisis Leverage of Attributes}

Atribut sensitif berperan bagi status keberlanjutan pada dimensi yg dikaji, atribut ini mampu mendorong keberlanjutan pada dimensi tarsebut. Atribut sensitif dilihat berdasarkan nilai Root mean Square (RMS). Penentuan atribut yang berkategori sensitif dapat dilakukan melalui tiga alternati yaitu (1) atribut yang memiliki nilai RMS $\geq$ 2\%; (2) ditentukan dengan cara memilah atribut yang memiliki nilai perubahan RMS (root mean square) lebih dari setengah skala nilai pada sumbu $\mathrm{x}$ (sensitivitas); atau (3) memilih atribut-atribut yang memiliki nilai RMS yang paling ekstrem pada sumbu y (Sukwika et al., 2016).

Berdasarkan hasil analisis Leverage Attributes (lihat Gambar 7) diketahui atribut sensitif pada dimensi-dimensi yang mengukur status keberlanjutan pengelolaan sampah terpadu di TPST Bantargebang sebagai berikut:

1. Teknik Pengolahan terdapat atribut open dumping (RMS=2,99) dan komposting (RMS $=2,56)$ sebagai pengungkit mendukung keberlanjutan pengelolaan sampah terpadu di TPST-Bantargebang. Dimensi aspek Teknik Pengolahan memiliki nilai indeks MDS 68,66. Menurut Razak (2015) pengolahan sampah sampah organik menjadi pupuk kompos memiliki nilai manfaat ekonomi yang layak dan berpengaruh pada penyerapan tenaga kerja lokal. Pada standar baku, pemprosesan sampah dapat mengurangi penimbunan sampah. Oleh karena itu, pengembangan tempat pembuangan akhir yang berawal dari hanya sekedar tempat penimbunan sampah harus didorong menjadi tempat pemprosesan sampah, mengarahkan open-dumping menjadi sanitary landfill dan estetika (Lumongga, 2014).

2. Ekonomi Bisnis terdapat atribut Investor 3R (RMS=3,08) dan Bank sampah (RMS=3,09) sebagai pengungkit mendukung keberlanjutan pengelolaan sampah terpadu di TPST- 
Bantargebang untuk dimensi aspek Ekonomi Bisnis yang bernilai MDS $=54,33$. Hernawati et al. (2013) dan Ismail (2018) merumuskan pengembangan TPS 3R melaui pengurangan pencemaran, kerjasama dengan pihak terkait, peningkatan peran pemangku kepentingan, dan pemilahan sampah, termasuk B3. Pengembangan pengelolaan bank sampah untuk mengurangi sampah anorganik yang dihasilkan oleh warga. Bank sampah dapat merupakan koperasi kerja sama antara pemerintah daerah dan corporate cocial responsibility (CSR) (A. S. Suryani, 2014) yang dilakukan secara sistematis dan masif dengan menggerakkan partisipasi masyarakat yang dilengkapi dengan berbagai fasilitas (Sujiyanto, 2016).

3. Kesejahteraan Sosial terdapat atribut kelola sampah partisipatif $(\mathrm{RMS}=5,30)$ dan Alternatif pekerjaan lain untuk pemulung $(\mathrm{RMS}=5,50)$ sebagai pengungkit mendukung keberlanjutan pengelolaan sampah terpadu di TPSTBantargebang untuk dimensi aspek Kesejakteraan Sosial yang bernilai MDS $=57,15$. Pada dimensi ini, atribut Penyerapan naker TPA tidak dipilih variable pengungkit (leverage) kareana nilai bad-scores nya kecil $(2,25)$ dibanding dengan kedua variable pengungkit tersebut diatas, yaitu 6,62 dan 7,16. Partisipasi masyarakat dalam pelaksanaan kegiatan pengelolaan sampah diintegrasikan dengan program pemerintah yang berkaitan dengan kegiatan keterampilan pembuatan produk dari limbah sampah sehingga masyarakat mampu untuk mengikuti kemajuan tekhnologi pengelolaan sampah dalam rangka mewujudkan kesejahteraan masyarakat (Sulistiyorini et al., 2015). Sementara Luthfi dan Kismini (2013) memandang diperlukan aksi bersama dan terpadu dari para pemangku kepentingan dalam rangka memberikan pendapingan kepada masyarakat dalam pengelolaan sampah, dan mensinergiskan pengetahuan dan pengalaman masyarakat tentang pengelolaan sampah melalui kegiatan-kegiatan yang diselenggarakan di TPA.

4. Regulasi Kelembagaan terdapat atribut LSM peduli lingkungan (RMS=4,98), Kebijakan daya dukung lingkungan (RMS=4,98), dan Sarana prasarana $(\mathrm{RMS}=3,36)$ sebagai pengungkit mendukung keberlanjutan pengelolaan sampah terpadu di TPST-Bantargebang untuk dimensi aspek Regulasi Kelembagaan yang bernilai MDS = 56,86 . Kebijakan daya dukung lingkungan di sekitar TPST Bantargebang akan terkait erat dengan perubahan kualitas lingkungan dan kesehatan masyarakat. Pemerintah lewat kebijakannya mendorong keterlibatan aktif masyarakat termasuk LSM dalam mengelola sampah. Hal tersebut diharapkan dapat mengubah perilaku masyarakat sehingga daya dukung lingkungan dapat terus dirasakan oleh masyarakat. Pengelolaan sampah perkotaan dapat dilakukan oleh unit atau badan apapun asalkan terdapat pembagian kerja, program, dan standar operasional prosedur (SOP) yang jelas. Selama ini, persoalaan sampah dikelola oleh dinas pekerjaan umum yang memiliki sarana prasarana untuk pengelolaan sampah (Sukwika, 2018). Sejalan dengan perkembangan organisasi pada pemerintah dan hubungan sampah dengan lingkungan hidup, maka keberadaan suatu badan yang dikhususkan untuk mengelola lingkungan menjadi sangat penting (S. A. Mulasari et al., 2014).

5. Manajemen Lingkungan terdapat atribut Minimisasi cemaran buangan sampah (RMS=2,40), Dayatampung sampah TPA (RMS=2,61), dan Kelompok pengumpul barang bekas (RMS $=1,87)$ sebagai pengungkit mendukung keberlanjutan pengelolaan sampah terpadu di TPST-Bantargebang untuk dimensi aspek Manajemen Lingkungan yang bernilai MDS $=50,02$. Kelompok pengumpul barang bekas dalam pengelolaan sampah dapat didorong mulai dari pra, proses, dan pascapengelolaan (Hernawati et al., 2013). Menurut Faizah (2008), pengelolaan menuju zero waste, proses pemilahan dan pengolahan harus dilaksanakan di sumber sampah, baik bersamaan maupun secara berurutan dengan pewadahan sampah.

6. Produksi Bersih terdapat atribut Sampah organik (RMS=2,92), PLTSa (RMS=2,02) dan IPAS (RMS=1,76) sebagai pengungkit mendukung keberlanjutan pengelolaan sampah terpadu di TPST-Bantargebang untuk dimensi aspek Produksi Bersih yang bernilai $\mathrm{MDS}=59,21$. Sampah organik di TPST Bantargebang paling dominan (55\%) dibanding jenis sampah lainnya (Fariz, 2016). PLTSa dengan proses pembakaran menggunakan proses konversi Thermal dalam mengolah sampah menjadi energi. PLTSa dapat menjadi pemecah permasalahan pengelolaan sampah dan mengurangi GRK seperti $\mathrm{CH}_{4}$ dan $\mathrm{CO}_{2}$ (Prasetiyo et al., 2017). IPAS (instalasi pengolahan air sampah) yang dilengkapi pengolahan lindi menggunakan model koagulasi dan sistem biofilter anaerobik dapat menurunkan angka kuman (Susanto et al., 2004). Diperlukan kolam IPAS untuk penampung dan pengolahan, stabilisasi dan maturase, aerasi dan filtrasi-sorpsi (Saleh, 2012).

Pada gambar heksagon (Gambar 8), di mana jumlah sisi tergantung pada jumlah bidang evaluasi. Skor ditransformasikan berdasarkan performa yang diskalakan antara 0 (kemungkinan terburuk) dan 10 (kemungkinan terbaik). Adapun warna dasar pada gambar heksagon merupakan indikasi kinerja dan menunjukkan apakah skor berada di antara 0-40,00\% (skor "gagal"), 40,01-70,00\% (skor "lulus"), atau 70,01-100\% (skor "baik"). 
Analisis Leverage Teknik Pengelolaan

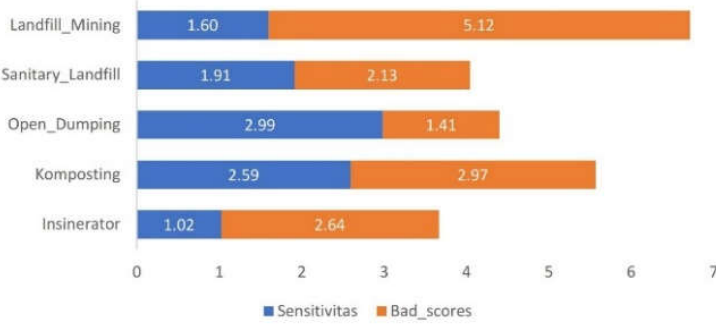

Analisis Leverage Kesejahteraan Sosial

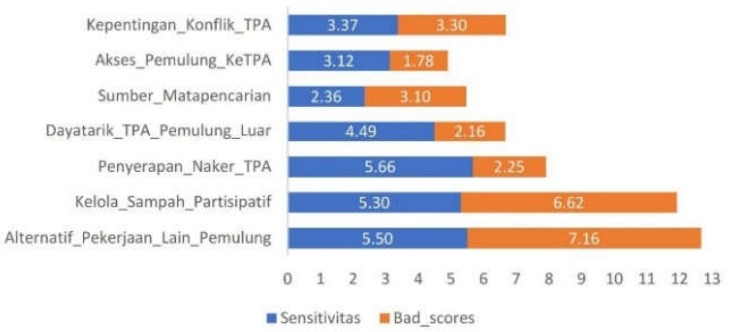

Analisis Leverage Regulasi Kelembagaan

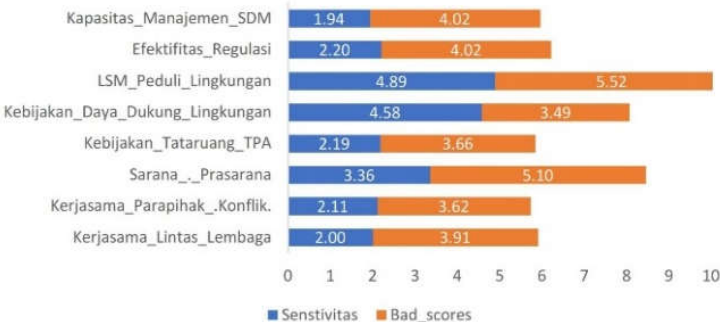

Analisis Leverage Produksi Bersih

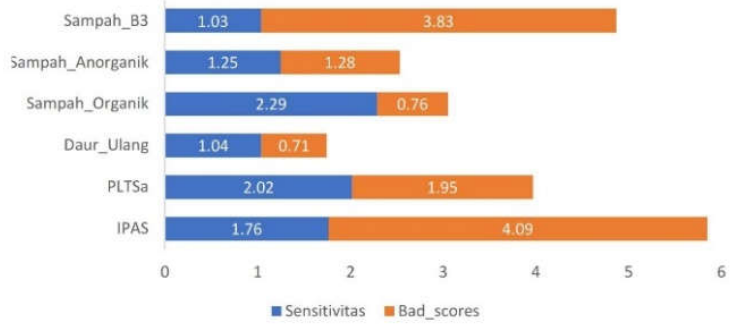

Analisis Leverage Ekonomi Bisnis

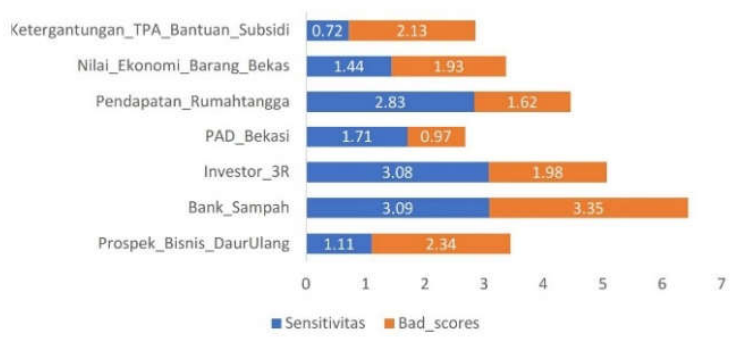

Analisis Leverage Manajemen Lingkungan

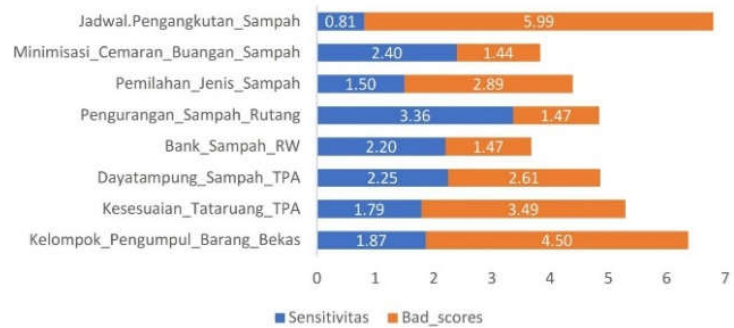

Root Mean Square Change in Ordination when Selected Attribute Removed (on Sustainability scale 0 to 100 )

Gambar 7 Analisis leverage pada status keberlanjutan: Sensitivitas dan bad-scores

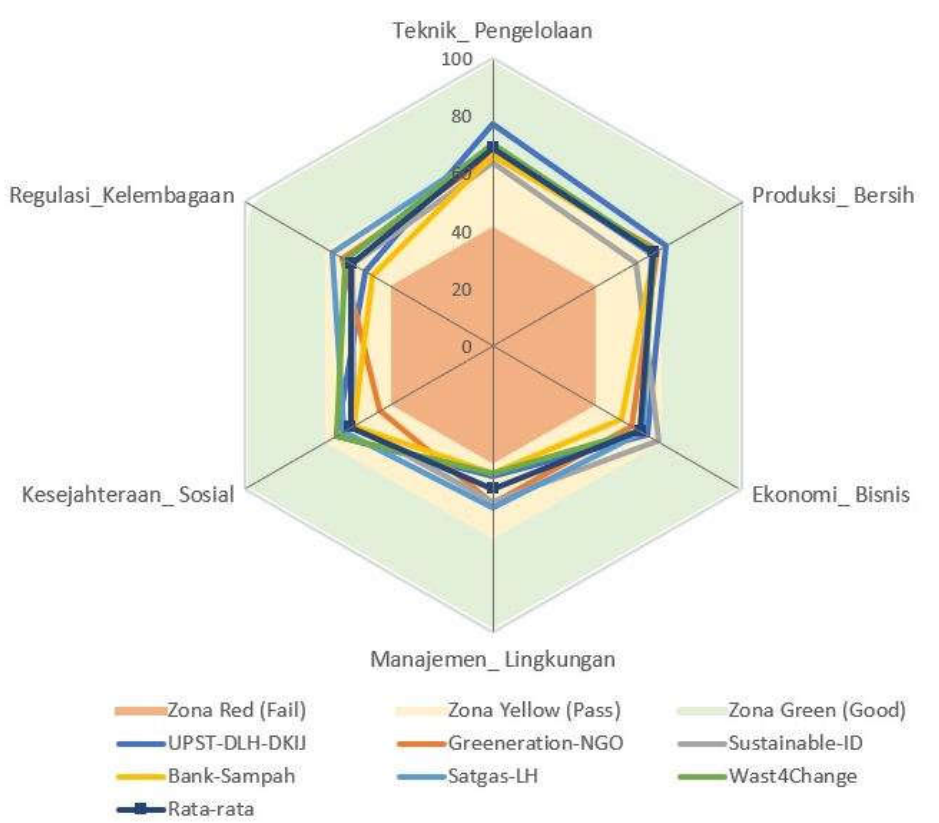

Keterangan: Zona hijau = skor 'baik' (70,01-100), zona kuning = skor 'lulus' $(40,01-70,00)$, dan zona merah = skor 'gagal' (0-40) (Orland \& Varkey, 2014)

Gambar 8. Diagram indeks keberlanjutan multidimensional enam aspek 


\section{Kesimpulan}

Status keberlanjutan pengelolaan sampah terpadu di TPST-Bantargebang antar stakeholder sangat beragam, secara rataan nilai indeks multidimensional berkisar di 51,71 atau termasuk dalam kategori berkelanjutan (lulus). Atribut yang sensitif berpengaruh terhadap pengelolaan sampah terpadu di TPST-Bantargebang sebanyak 15 atribut, yaitu dari dimensi: (a) Teknik Pengolahan (open dumping dan komposting); (b) Ekonomi Bisnis (Investor 3R dan Bank sampah); (c) Kesejahteraan Sosial (Kelola sampah partisipatif dan Alternatif pekerjaan lain pemulung); (d) Regulasi Kelembagaan (LSM peduli lingkungan, Kebijakan dayadukung lingkungan, dan Sarana prasarana); (e) Manajemen Lingkungan (Minimisasi cemaran buangan sampah, Dayatampung sampah TPA, dan Kelompok pengumpul barang bekas); dan (f) Produksi Bersih (Sampah organik, PLTSa, dan IPAS). Hasil uji statistik menunjukkan bahwa metode Rap-TPST baik untuk dipergunakan sebagai salah satu alat untuk mengevaluasi status keberlanjutan terhadap pengelolaan sampah terpadu di TPST-Bantargebang kota Bekasi melalui pendekatan rapid appraisal.

Pengolahan sampah di TPST Bantargebang menerapkan pendekatan landfill mining untuk pengembangan kapasitas guna memperluas atau menambah luas lahan serta memperpanjang umur TPST Bantargebang. Produk landfill mining berupa (UPTPST, 2020): Kompos, digunakan (reuse) untuk penghijauan area TPST Bantargebang; Tanah/ kompos, sebagai cover soil; Sampah anorganik, dipilah lalu diproses menjadi refused derived fuel (RDF), dimanfaatkan (recycle) atau diinsinerasi di PLTSa.

Pemutakhiran pengembangan tekologi pengolahan sampah di TPST-Bantargebang terus dilakukan, dimana akan dibangun waste to energy sebanyak 3-5 unit untuk mereduksi (reduce) 18 juta $\mathrm{m}^{3}$ sampah. Sebelumnya TPST-Bantargebang telah mengembangkan PLTSa. Nilai strategis PLTSa yang dirancang menggunakan teknologi proses termal untuk mengurangi volume sampah secara cepat dan signifikan, ramah lingkungan dam menghasilakan produk samping listrik. Hal ini sesuai Perpres 35 tahun 2018 tentang percepatan pembangunan infrastruktur pengolahan sampah menghasilkan energi listrik berbasis teknologi ramah lingkungan.

Secara multidimensional, upaya-upaya produktif yang sudah dilakukan di TPST-Bantargebang menunjukkan kinerja yang berkelanjutan (pass). Oleh karena itu, ke depan TPST-Bantargebang perlu didorong juga menjadi pusat studi persampahan dan Eco Industrial Park.

\section{UCAPAN TERIMA KASIH}

Terima kasih kepada LPPM Universitas Sahid Jakarta. Penelitian ini tidak menerima dana eksternal.

\section{DAFTAR PUSTAKA}

Aditya, B. R. (2014). Sinergitas stakeholders untuk administrasi publik yang demokratis dalam perspektif teori governance (Studi kasus: TPST Mulyoagung Malang). Jurnal Administrasi Publik, 2(3), 407-413.

Aprilia, A. (2016). Household solid waste management in Jakarta, Indonesia: Evaluation on human behaviour, economy, and GHG emissions. (Dissertation), Kyoto University, Japan. Retrieved from https://repository.kulib.kyoto-

u.ac.jp/dspace/bitstream/2433/215970/2/denek00 336.pdf

Asteria, D., \& Heruman, H. (2016). Bank sampah sebagai alternatif strategi pengelolaan sampah berbasis masyarakat di Tasikmalaya. J. Manusia Dan Lingkungan, 23(1), 136-141. doi:10.22146/jml.18783

Brancato, G., Macchia, S., Murgia, M., Signore, M., Simeoni, G., Blanke, K., . . . Hoffmeyer-Zlotnik, J. (2006). Handbook of recommended practices for questionnaire development and testing in the European statistical system. Italy: European Commission.

Darwati, S., \& Anggraini, F. (2012). Peran komunitas dalam pengelolaan sampah berbasis pola pilah kumpul olah terhadap reduksi sampah kota. Jurnal Permukiman, 7(1), 24-32. doi:10.31815/jp.2012.7.24-32

Dirjen-Cipta-Karya. (2012). Materi diseminasi keteknikan bidang persampahan (buku I). Jakarta: Direktorat Jenderal Cipta Karya Kementerian Pekerjaan Umum

DKI-Jakarta, P. Keputusan Bersama Pemprov DKI Jakarta dengan Pemkot Bekasi No.3428/072 dan No. 658.1/Kep.439 tentang Penjanjian kerjasama pengelolaan sampah dan tempat pembuangan akhir (TPA) sampah di kecamatan Bantargebang kota Bekasi, (2003).

DKI-Jakarta, P. Peraturan Daerah Provinsi Daerah Khusus Ibukota Jakarta No. 3 tentang Pengelolaan sampah (2013).

DKI-Jakarta, P. Instruksi Gubernur Provinsi Daerah Khusus Ibukota Jakarta No. 8 tentang Penerapan pengelolaan sampah kawasan secara mandiri, (2016a).

DKI-Jakarta, P. Keputusan Kepala Dinas Kebersihan Provinsi Daerah Khusus Ibukota Jakarta No. 117 tentang Pelaksanaan pengelolaan sampah pada kawasan secara mandiri (2016b).

DKI-Jakarta, P. Peraturan Gubernur No. 50 tentang Pembangunan dan pengoperasian fasilitas pengelola sampah di dalam kota/intermediate treatment facility (2016c).

DKI-Jakarta, P. Keputusan Kepala Dinas LH No. 374 tentang Persyaratan teknis izin usaha pengelolaan sampah (2017).

Faizah. (2008). Pengelolaan sampah rumah tangga berbasis masyarakat di kota Yogyakarta. (Tesis), Universitas Diponegoro, Semarang.

Fariz, F. (2016). Mekanisme pengelolaan limbah padat serta pemanfaatan hasil pengolahan di TPST Bantargebang. (Skripsi), Universitas Sahid, Jakarta.

Farrance, I., \& Frenkel, R. (2014). Uncertainty in measurement: a review of monte carlo simulation using microsoft excel for the calculation of uncertainties through functional relationships, including uncertainties in empirically derived constants. The Clinical biochemist. Reviews, 35(1), 37 61. 
Goldstein, N., Dietzel, C., \& Clarke, K. (2019). Sensitivity testing of monte carlo iterations for model calibration, $1-9$. Retrieved from http://ncgia.ucsb.edu/projects/gig/Repository/refer ences/SLEUTHPapers_Nov24/GoldsteinGeoComputat ion05.pdf

Handayani, D. S., Budisulistiorini, S. H., \& Nuraini, M. R. (2009). Kajian nilai ekonomi penerapan konsep daur ulang pada TPA Jatibarang kota Semarang. Jurnal PRESIPITASI, 7(2), 35-44.

Hermawan, F. (2017). Penerapan teknologi waste to energy (WTE) pada rencana pembangunan intermediate treatment facility (ITF) Sunter Jakarta Utara. Paper presented at the Teknologi Waste to Energi (WTE) dalam Penerapannya di Provinsi DKI Jakarta - ITF Sunter April 2017, Jakarta. https://upst.dlh.jakarta.go.id/files/Research_PaperMakalah_Waste_to_Energy_\%28WTE_Plant_di_Sunter _Jakarta_Utara_Indonesia\%29.pdf

Hernawati, D., Saleh, C., \& Suwondo. (2013). Partisipasi masyarakat dalam pengelolaan sampah berbasis $3 \mathrm{R}$ (reduce, reuse dan recycle): Studi pada tempat pengelolaan sampah terpadu di Desa Mulyoagung kecamatan Dau kabupaten Malang. Jurnal Administrasi Publik, 1(2), 181-187.

Indonesia, R. Undang-Undang No. 18 tentang Pengelolaan sampah, (2008).

Indonesia, R. Peraturan Menteri Dalam Negeri No. 33 tentang Pedoman pengelolaan sampah (2010).

Indonesia, R. (2018). Peraturan Presiden No. 35 tentang Percepatan pembangunan instalasi pengolah sampah menjadi energi listrik berbasis teknologi ramah lingkungan.

Ismail, G. (2018). Analisis keberlanjutan tempat pengolahan sampah 3R di kota Bogor: Studi Kasus TPS 3R Kencana dan Cipaku Bogor. (Tesis), IPB Unibersity, Bogor. Retrieved from https://repository.ipb.ac.id/jspui/bitstream/123456 789/95596

Kavanagh, P., \& Pitcher, T. J. (2004). Implementing microsoft excel software for rapfish: A Technique for the rapid appraisal of fisheries status (Fisheries Centre Research Reports 2004 Vol. 12 No. 2. Vancouver, Canada: University of British Columbia). Retrieved from https://open.library.ubc.ca/media/download/pdf/52 383/1.0074801/1

Kholil, Dharoko, T. A., \& Widayati, A. (2015). Multidimensional scaling approach to evaluate sustainability of Cirata reservoir - West Java Province. J. Manusia Dan Lingkungan, 22(1), 22-31. doi:10.22146/jml.18721

Khulaemi, A. (2010). Pemanfaatan sampah menjadi tenaga listrik: Study kasus pada pembangkit listrik tenaga sampah Bantargebang. Forum Teknologi, 5(1), 39-45.

Kim, S. H., Song, M. S., Sun, G. M., \& Shin, C. H. (2016). A proposal on accuracy estimation method for the sampling-based uncertainty analysis with Monte Carlo simulation technique. Journal of Nuclear Science and Technology, 53(2), 295-301. doi:10.1080/00223131.2015.1038665

Kristina, H. J. (2014). Model konseptual untuk mengukur adaptabilitas bank sampah di Indonesia. Jurnal Teknik Industri, 9(1), 19-28. doi:10.12777/jati.9.1.19-28

Lumongga, R. I. (2014). Tinjauan kebijakan lingkungan hidup terhadap standar baku pemilihan lokasi tempat pembuangan akhir sampah. Jurnal Sosek Pekerjaan Umum, 6(2), 78-139.

Luthfi, A., \& Kismini, E. (2013). Partisipasi masyarakat dalam sistem pengelolaan sampah di TPA sukoharjo kabupaten Pati. Jurnal Abdimas, 17(1), 1-8.

Manurung, D., Bintoro, H. M. H., Hadi, S., \& Lubis, I. (2016). Analysis of related area preference with regional sanitary landfill in temporary Bantargebang sanitary landfill using topsis method. Jurnal Teknologi Lingkungan, 17(2), 73-81. doi:10.29122/jtl.v17i2.27

Moruff, M. (2012). Cultural understanding of space and waste disporsal habit among the urban populace in Ibadan Metropolis, South Western Nigaria. Journal of Sustainable Development, 14(4), 82-95.

Mulasari, A., Husodo, A. H., \& Muhadjir, N. (2016). Analisis situasi permasalahan sampah kota Yogyakarta dan kebijakan penanggulangannya. Jurnal Kesehatan Masyarakat, 11(2), 1-11. doi:10.15294/kemas.v11i1.3521

Mulasari, S. A., Husodo, A. H., \& Muhadjir, N. (2014). Kebijakan pemerintah dalam pengelolaan sampah domestik. Kesmas: National Public Health Journal, 8(8), 404-410. doi:10.21109/kesmas.v8i8.412

Mulyadin, R. M., Iqbal, M., \& Ariawan, K. (2018). Konflik pengelolaan sampah di DKI Jakarta dan upaya mengatasinya. Jurnal Analisis Kebijakan Kehutanan, 15(2), 179-191. doi:10.20886/jakk.2018.15.2.179191

Nurdiani, N. (2014). Teknik sampling snowball dalam penelitian lapangan. ComTech, 5(2), 1110-1118.

Orland, C., \& Varkey, D. (2014). Rapfish introduction: Kite plots in $\mathrm{R}$ statistics. Retrieved from http://www.rapfish.org/software

Peres-Neto, P. R., Jackson, D. A., \& Somers, K. M. (2003). Giving meaningful interpretation to ordination axes: assessing loading significance in principal component analysis. Ecology, 84(9), 2347-2363.

Pitcher, T., Lam, M., Ainsworth, C., Martindale, A., Nakamura, K., Perry, R., \& Ward, T. (2013). Improvements to Rapfish: A rapid evaluation technique for fisheries integrating ecological and human dimensions. Journal of Fish Biology, 83(4), 865-889. doi:10.1111/jfb.12122

Pitcher, T. J., \& Preiksho, D. (2001). RAPFISH: a rapid appraisal technique to evaluate the sustainability status of fisheries. Fish Res, 49, 255-270.

Prasetiyo, A. T., Notosoedjono, D., \& Waryani. (2017). Studi evaluasi pembangkit listrik tenaga sampah di tempat pengolahan sampah terpadu Bantargebang. Jurnal JOM Teknik Elektro, 1(1), 1-11.

RAPFISH. (2011). Rapfish evaluation fields for rapid appraisal of compliance with article 7 of the FAO code of conduct for responsible fisheries, covering fisheries management. Retrieved from http://www.rapfish.org/evaluation-fieldsattributes/time-tracker

Razak, R. (2015). Analisis manfaat ekonomi dan strategi pengembangan unit pengelolaan sampah organik (UPS) di kota Depok. (Skripsi), IPB University, Bogor. Retrieved

from https://repository.ipb.ac.id/handle/123456789/830 91

Ronasifah, F., Ati, N. U., \& Hayat. (2019). Peran lembaga swadaya masyarakat (LSM) cakrawala keadilan dalam pemberdayaan lingkungan (Studi tentang gerakan 
peduli sampah di desa Paciran kabupaten Lamongan). Jurnal Respon Publik, 13(3), 53-61.

Saleh, C. (2012). Studi perencanaan instalasi pengolahan limbah lindi sebagai kontrol pemenuhan baku mutu sesuai kepmen 03/91 (studi kasus pada Tpa Supit Urang Malang). Media Teknik Sipil, 10(2), 87-94. doi:10.22219/jmts.v10i2.1782

Salganik, M. J., \& Heckathorn, D. D. (2007). Sampling and estimation in hidden populations using respondentdriven sampling. Journal Sociological Methodology, 34(1), 193-240. doi:10.1111/j.00811750.2004.00152.x

Sudirman. (2012). Implementasi 3R melalui bank sampah. Jakarta: Kementrian Lingkungan Hidup.

Sujiyanto. (2016). Analisis pengelolaan sampah di bank sampah malang. Jurnal Ilmu Sosial dan Ilmu Politik, 5(3), 115-122.

Sukwika, T. (2018). Peran pembangunan infrastruktur terhadap ketimpangan ekonomi antarwilayah di Indonesia. Jurnal Wilayah dan Lingkungan, 6(2), 115130. doi:10.14710/jwl.6.2.115-130

Sukwika, T., Darusman, D., Kusmana, C., \& Nurrochmat, D. R. (2016). Evaluating the level of sustainability of privately managed forest in Bogor, Indonesia. Biodiversitas, Journal of Biological Diversity, 17(1), 241-248. doi:10.13057/biodiv/d170135

Sukwika, T., Darusman, D., Kusmana, C., \& Nurrochmat, D. R. (2018). Skenario kebijakan pengelolaan hutan rakyat berkelanjutan di Kabupaten Bogor. Jurnal Pengelolaan Sumberdaya Alam dan Lingkungan, 8(2), 207-215. doi:10.29244/jpsl.8.2.207-215

Sulistiyorini, N. R., Darwis, R. S., \& Gutama, S. (2015). Partisipasi masyarakat dalam pengelolaan sampah di lingkungan margaluyu kelurahan Cicurug. Share Social Work Journal, 5(1), 1-10. doi:10.24198/share.v5i1.13120

Suryani, A. S. (2014). Peran bank sampah dalam efektivitas pengelolaan sampah. Aspirasi, 5(1), 71-84.

Suryani, A. S. (2014). Peran bank sampah dalam efektivitas pengelolaan sampah di Malang. Aspirasi: Jurnal Masalah-Masalah Sosial, 5(1), 71-84. doi:10.22212/aspirasi.v5i1.447

Susanto, J. P., Ganefati, S. P., Muryani, S., \& Hani Istiqomah, S. (2004). Pengolahan lindi (leachate) dari TPA dengan sistem koagulasi - biofilter anaerobic. Jurnal Teknologi Lingkungan, 5(3), 167-173. doi:10.29122/jtl.v5i3.312

UPTPST. (2020). Tempat pengelolaan sampah terpadu Bantargebang. Retrieved from https://upst.dlh.jakarta.go.id/tpst/index

Widianto, A. I. (2007). Implementation of public private partnership in managing Bantargebang solidwaste disposal in Bekasi municipality. (Tesis), Universitas Gadjah Mada, Yogyakarta.

Widodo, E., \& Mukhtar. (2000). Konstruksi ke arah penelitian deskriptif. Yogyakarta: Avyrouz.

Wikaningrum, T. (2015). The policy of industrial estate environmental management complying to the green rating of "PROPER KLHK". (Thesis), IPB University, Bogor. Retrieved from https://repository.ipb.ac.id/jspui/bitstream/123456 789/79158/1/2015twi.pdf

Winahyu, D., Hartoyo, S., \& Syaukat, Y. (2013). Strategies of final disposal site (TPA) management of Bantargebang, Bekasi. Jurnal Manajemen Pembangunan Daerah, 5(2), 1-17. 